\title{
Ontogenetic color changes may strengthen suggestion about systematic affinities between two species of Chironius (Serpentes, Colubridae)
}

\author{
Otavio A. V. Marques ${ }^{1} \&$ Ivan Sazima ${ }^{2}$ \\ ${ }^{1}$ Laboratório de Herpetologia, Instituto Butantan, 05535-900 São Paulo, SP, Brazil. E-mail: \\ otaviomarques@butantan.gov.br. \\ 2 Departamento de Zoologia and Museu de História Natural, Universidade Estadual de Campinas, C.P. 6109, 13083- \\ 970, Campinas, SP, Brazil
}

Keywords: Serpentes, Colubridae, Chironius laevicollis, Chironius scurrulus, ontogenetic color change, systematic affinities.

The neotropical colubrid snakes of the genus Chironius include 20 species that dwell mainly in rainforests of Central and South America (Dixon et al. 1993). These medium to large snakes are diurnal, arboreal to terrestrial, and feed upon frogs (Dixon et al. 1993, Sazima and Haddad 1992, Marques et al. 2001). Several species are arboreal and their ground color are green (e.g. Campbell and Lamar 1989, Dixon et al. 1993, Marques et al. 2001). Their morphology also reflect their arboreal habits as these snakes have large eyes, slender bodies, and long tails (Dixon et al. 1993, Marques 1998).

Ontogenetic color changes are common within the genus, juveniles sometimes differing markedly from adults (Dixon et al. 1993, Marques et al. 2001). Chironius flavolineatus is regarded as the only species with no ontogenetic color changes (Dixon et al. 1993), but a close examination of preserved juvenile specimens revealed faint cross-bands in some of them (OAVM, pers. obs.). Upon examining preserved specimens Dixon et al. (1993) note that only $C$. laevicollis and $C$. scurrulus juveniles have

Received 24 April 2003

Accepted 20 August 2003

Distributed 31 October 2003 uniform color, albeit different from that presented by adults. Here we present the notable color ontogenetic changes recorded in life for these two species of Chironius and relate these changes to their proposed systematic affinities (Dixon et al. 1993).

We examined live individuals of Chironius laevicollis and C. scurrulus in the field and captivity, photographs of live individuals, and preserved specimens in the herpetological collection of the Instituto Butantan (IB). In both species the ground color of neonates and juveniles up to $30 \mathrm{~cm}$ SVL is uniformly green (Figure 1A, D). In larger juveniles and adults the ground color is yellowish brown ( $C$. laevicollis) or reddish brown ( $C$. scurrulus), the fore-body black with posterior dorsal scales edged with black or dark brown (Figure 1B, E). As the snakes grow larger, their hind-body become gradually darker, and in very large individuals the ground color is black (Figure 1C, F).

Recent studies on morphology and feeding habits indicate that the extent of arboreality differ among Chironius species from the Atlantic forest of southeast Brazil (Marques 1998, Marques and Sazima in press). Chironius laevicollis has a stout body, short tail and feed mostly on leptodactylids, showing the typically 
A

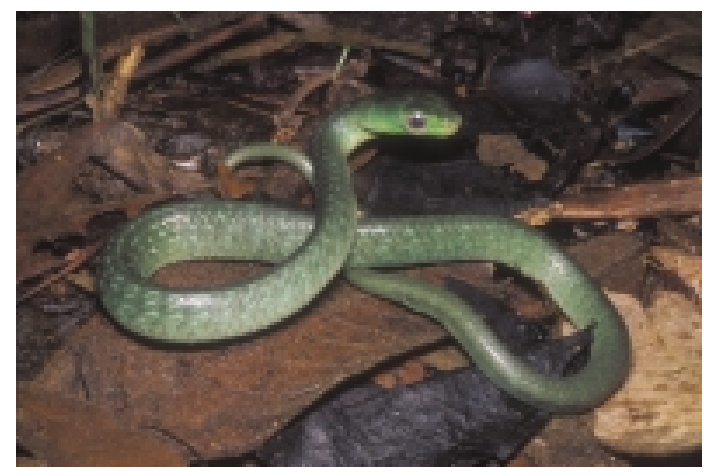

B

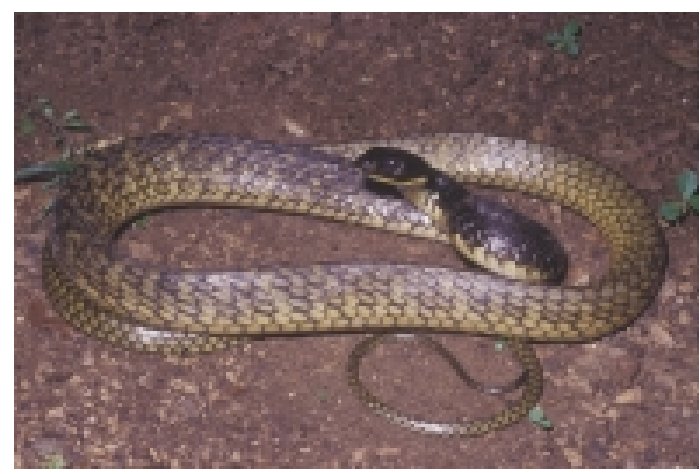

C

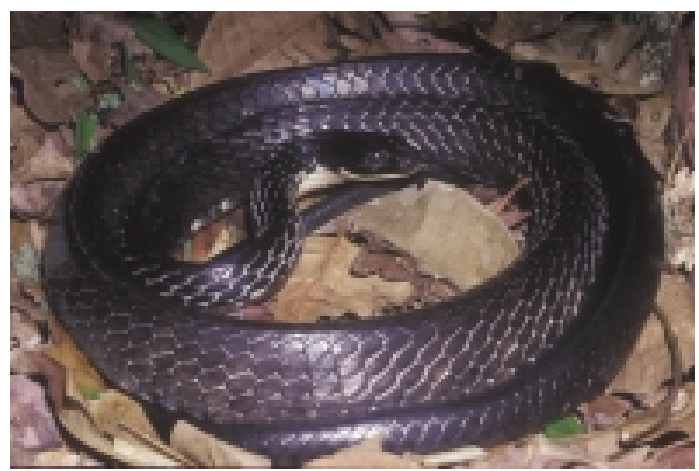

D

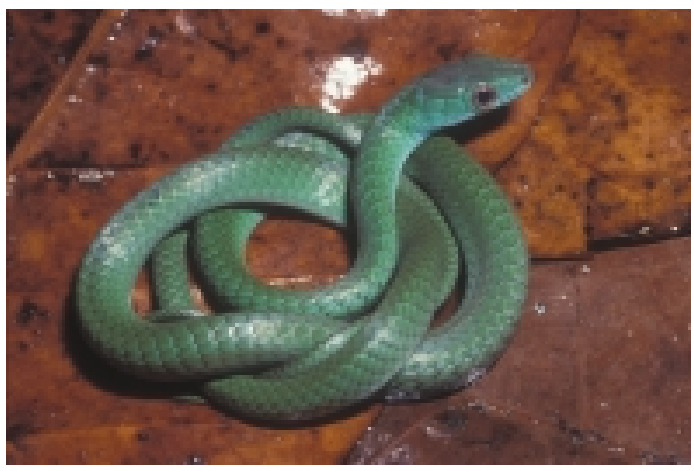

E

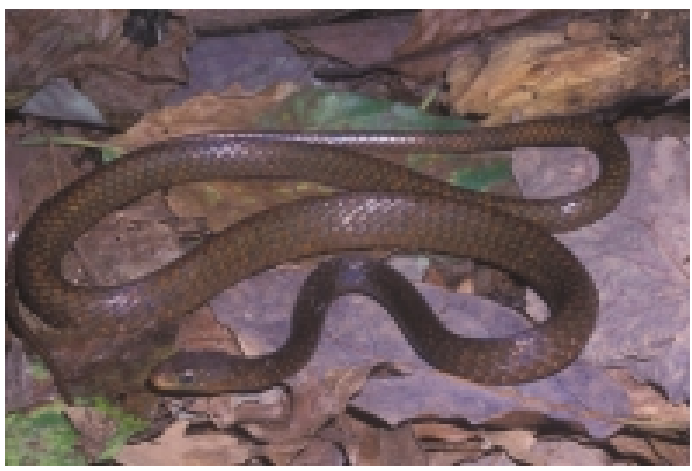

$\mathbf{F}$

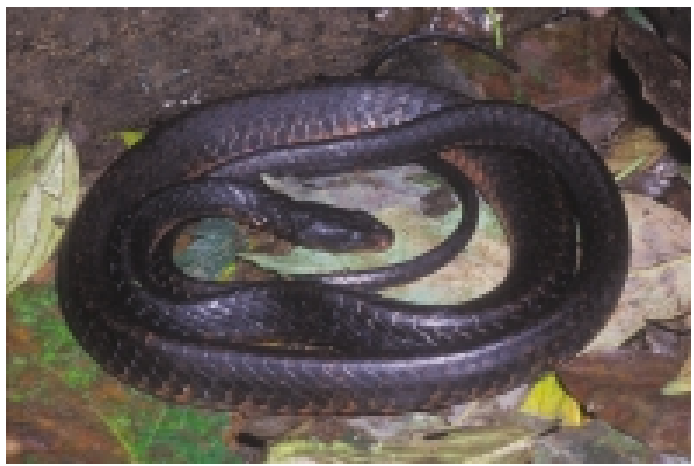

Figure 1 - Ontogenetic colour changes in Chironius laevicollis (A-C) and C. scurrulus (D-F), juveniles (A and D), small adults (B and E), and large adults (C and F). Chironius laevicollis lengths and collection numbers: (A) about $300 \mathrm{~mm}$ TL, unregistered; (B) $1250 \mathrm{~mm} \mathrm{SVL}, 560 \mathrm{~mm}$ tail length, unregistered; (C) $1435 \mathrm{~mm}$ SVL, $620 \mathrm{~mm}$ tail length, IB 57096. The same for C. scurrulus: (D) $313 \mathrm{~mm}$ SVL, $136 \mathrm{~mm}$ tail length, unregistered; (E) $1030 \mathrm{~mm}$ SVL, $510 \mathrm{~mm}$ tail length, IB 65723; (F) $1160 \mathrm{~mm}$ SVL, $550 \mathrm{~mm}$ tail length; IB 65004. Juvenile C. scurrulus photographed by M. Martins. 
terrestrial trends within the genus (Marques 1998, Marques et al. 2001). Our field records of active adults are all on the ground $(n=8)$ whereas other Chironius species from the Atlantic forest use vegetation habitually or at least more extensively (Sazima and Haddad 1992, Marques and Sazima in press, pers. obs.). Of three $C$. laevicollis juveniles we recorded in the field, one was in a bromeliad above the ground, the other was climbing a shrub about $1.5 \mathrm{~m}$ tall, and the third was crossing a dirty road. Thus, the green color of juveniles is possibly related to their more pronounced arboreal habits. Field data on $C$. scurrulus is scarce but this snake is primarily terrestrial when active, and uses vegetation to rest by day and to sleep at night (Martins and Oliveira 1999). We suggest that juveniles of $C$. scurrulus are more arboreal than the adults, similarly to what we recorded for $C$. laevicollis.

Dixon et al. (1993) propose that $C$. laevicollis and C. scurrulus are relatively young sister species. Differentiation between these two species may have occurred during the last fragmentation between Amazonian and Atlantic forest 300,000-800,000 years ago (Zamudio and Greene 2000). The similarity of color ontogenetic changes shown here, and unrecorded for any other Chironius species to date, may strengthen the sister species concept suggested by Dixon et al. (1993).

Martins and Oliveira (1999) suggest that the green juveniles of $C$. scurrulus mimic the also green, mildly venomous and aggressive colubrid Philodryas viridissimus, and a similar suggestion may perhaps apply to the pairs $C$. laevicollis- $P$. olfersii in the northern portion and C. laevicollis-P. aestivus in the southern portion of the Atlantic forest (Marques et al. 2001). Both Philodryas species show arboreal habits (Sazima and Haddad 1992, Martins and Oliveira 1999, Marques et al. 2001) as do the juveniles of the two Chironius species commented here.

\section{Acknowledgements}

We thank H. Ferrarrezzi for valuable suggestions on the manuscript; V. J. Germano for expert opinion and help with the herpetological collection of the Instituto Butantan; M. Martins for the C. scurrulus juvenile photo; CNPq and FAPESP for essential financial support.

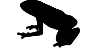

\section{References}

Campbell, J. A. and W. W. Lamar. 1989. The Venomous Reptiles of Latin America. Ithaca, New York. Cornell University Press. $425 \mathrm{pp}$.

Dixon, J. R., J. A. Wiest and J. M. Cei. 1993. Revision of the tropical snake Chironius Fitzinger (Serpentes, Colubridae). Museo Regionale di Scienze Naturali Monografie 13: 1-279.

Marques, O. A. V. 1998. Composição faunística, história natural e ecologia de serpentes da Mata Atlântica, na região da Estação Ecológica Juréia-Itatins, SP. Unpublished Ph.D. Thesis. Universidade de São Paulo, Brazil.

Marques, O.A.V. and I. Sazima. História natural dos répteis da Estação Ecológica Juréia-Itatins. Pp. 254-274 in O. A. V. Marques and W. Duleba (eds.), Estação Ecológica Juréia-Itatins: Ambiente Físico, Flora e Fauna. Ribeirão Preto. Holos. (in press.)

Marques, O. A. V., A. Eterovic and I. Sazima. 2001. Serpentes da Mata Atlântica - guia ilustrado para a Serra do Mar. Ribeirão Preto. Holos. 184 pp.

Martins, M. and M. E. Oliveira. 1998. Natural history of snakes in forests of the Manaus region, Central Amazonia, Brazil. Herpetological Natural History 6: 78-150.

Sazima, I. and C. F. B. Haddad, 1992. Répteis da Serra do Japi: notas sobre história natural. $\mathrm{Pp}$ 212-236 in $\mathrm{H}$. F. Leitão-Filho and L. P. C. Morellato (orgs.), História Natural da Serra do Japi - ecologia e preservação de uma área florestal no sudeste do Brazil. Campinas. Editora Unicamp.

Zamudio, K. and H. W. Greene. 1997. Phylogeography of the bushmaster (Lachesis muta: Viperidae): implications for neotropical biogeography, systematics, and conservation. Biological Journal of the Linnean Society 62: 421-442. 